\title{
Morphology and Histological Annual Changes of the Oviduct of Chaetophractus villosus (Mammalia, Xenarthra, Dasypodidae)
}

\author{
Morfología y Cambios Histológicos Anuales del Oviducto de \\ Chaetophractus villosus (Mammalia, Xenarthra, Dasypodidae)
}

"Stella Maris Codón \& ** Emma Beatriz Casanave

CODÓN, S. M. \& CASANAVE, E. B.Morphology and histological annual changes of the oviduct of Chaetophractus villosus (Mammalia, Xenarthra, Dasypodidae). Int. J. Morphol., 27(2):355-360, 2009.

SUMMARY: The morphological features of the oviduct in the armadillo Chaetophractus villosus (Desmarest, 1804) were studied. In the simple columnar epithelium, ciliated cells, secretory cells, and cells of the bottom of the folds are described. The most remarkable findings are the increase in number of ciliated cells, when present, from the fimbriae to the uterus, being the isthmus practically lined by ciliated cells, and that secretory cells are more abundant in the apical zone of the ampulla and fimbriae, than in the isthmus. Morphological changes along the year in the different portions are described.

KEY WORDS: Xenarthra; Armadillo; Chaetophractus villosus; Morphology; Oviduct.

\section{INTRODUCTION}

The mammalian oviduct is a pair tubular organ, with simple columnar epithelium formed by two kinds of cells, ciliated and secretory (Kamaci et al., 1999; Steffl et al., 2004; Yániz et al., 2000, 2006). Concerning to the oviduct of armadillos, there are only few references on its morphological features in Dasypus novemcinctus (Enders \& Buchanan, 1959) and D. hybridus (Cuba Caparo, 1979); almost nothing is known about this structure in C. villosus (Codón \& Casanave, 1996, 2000; Cetica et al., 2005).

It has long been stated in mammals that the oviductal epithelium undergoes morphological changes, both depending on the portion and the phase of the oestrous cycle (Shirley \& Reeder, 1996; Abe et al., 1999, Yániz et al., 2000), which may be related to the period of the year. Nothing is known in $C$. villosus.

In this work, we describe the different kind of cells of the oviduct in the armadillo $C$. villosus, as well as the changes that occur in its different portions along the year.

\section{MATERIAL AND METHOD}

Twenty-two sexually matures females Chaetophractus villosus (n.v. "peludo"), weighing between 1.820 and $3.705 \mathrm{~g}$. were used. They were obtained along the year from the wild population, in Bahía Blanca area (southwest of the Buenos Aires Province, Argentina), and euthanized with $75 \mathrm{mg} / \mathrm{kg}$ sodium tiopentate (i.p.). Relations of the oviduct were observed and photographed in situ.

Reproductive tracts were removed and oviducts were processed for microscopy. They were fixed in Bouin fixative, dehydrated and embedded in paraffin wax for serial sections $5-7 \mu \mathrm{m}$ thickness and stained with hematoxylin-eosin, Masson's trichrome, periodic acid Schiff reaction (PAS) and, for identification of basal bodies, ferric hematoxilin. Also, small pieces of different segments of the oviducts were immersed in $2.5 \%$ glutaraldehyde in $0,1 \mathrm{M}$ sodium cacodylate buffer at $\mathrm{pH} 7.4$, at $4{ }^{\circ} \mathrm{C}$, for 12 hours and postfixed in osmium tetroxide in the same buffer, at $4{ }^{\circ} \mathrm{C}$, for 1 hour; they were dehydrated in graded acetone and infiltrated in low-density resin (Spurr); semithin sections were stained with toluidine blue. All sections were examined with a Nikon AFM microscopy and photographed.

Laboratorio de Histología Animal, Departamento de Biología, Bioquímica y Farmacia, Universidad Nacional del Sur (U.N.S.), Bahía Blanca, Argentina.E-mail smcodon@criba.edu.ar

** Laboratorio de Fisiología Animal, Departamento de Biología, Bioquímica y Farmacia, U.N.S., Bahía Blanca, Argentina; Member of the Researcher Career of the Consejo Nacional de Investigaciones Científicas y Técnicas (CONICET), Argentina, E-mail: casanave@criba.edu.ar The paper was supported by Secretaría General de Ciencia y Tecnología, UNS, Project 24/B122, and by ANPCyT, PICTR 074/02. 


\section{RESULTS}

The oviducts are paired tubes extending from the ovary to the uterus, and consist of four portions (Fig. 1), a) Infundibulum: enlarged funnel-shaped region, adjacent to the ovary; fringed extensions, fimbriae (Fig. 2), extend from the mouth of the infundibulum toward the ovary. b) Ampulla: tubular portion, with broad lumen, coiled around the cranial pole of the ovary. c) Isthmus: constricted and less coiled portion; begins in the cranial pole of the ovary and extends to the middle line, ventrally to the ovary; is the narrow, medial segment adjacent to the uterus. d) Utero-tubal junction: segment with small lumen that go through the uterine wall.

The wall of the oviduct has three conspicuous layers: tunica mucosa, tunica muscularis and adventice or tunica serosa. The highly folded mucosa consists of an epithelium overlying a thin corion made up of loose connective tissue, which penetrates into the mucosal folds. The longitudinal folds decrease in height, number and complexity from the ampulla to the uterus and concurrently the lumen decrease in wide. The folds in the ampulla are numerous and complex in branching with one or more secondary branches (Fig. 3). In the isthmus they are simple, without secondary branches and medium in height (Fig. 4). In the utero-tubal junction they are simple and lower (Fig. 5). The epithelium lining the oviduct is simple columnar and consists of columnar ciliated cells, columnar secretory cells and cells of the bottom of the folds (Fig. 6). The height of the epithelium varies during the cycle, been largest from the end of winter to the middle of spring.

The ciliated cells (Fig. 7) have wide, clear cytoplasm; the apical zone is rounded and present cilia in certain periods of the year. When cilia were not observed, ciliated cells were identified demonstrating the presence of basal bodies with ferric hematoxiline. The nucleus is large, rounded or oval with basal or central position, basophilic and with chromatin in fine granules. The ciliated cells are intermingled with the secretory cells in all segments of the oviduct.

The secretory cells (Fig. 7), present in all segments of the oviduct, are narrower than ciliated cells, with basophilic cytoplasm and occasionally apical protrusions, which extend into the lumen and may hold the nucleus. This one is oval, generally laterally flattened, and basophilic, with basal or apical position and chromatin in dense granules.

The cells of the bottom of the folds (Fig. 6), with or without cilia, have weakly stained cytoplasm and are lower than the other cells. The nucleus is rounded, light, and central, with chromatin in fine granules.
The muscular layer composed of smooth muscle fibbers, thickens progressively towards the uterus. In the ampulla it is difficult to discern the arrangement of the fibbers, although an inner circular layer and an outer longitudinal one predominate, fundamentally in the proximal portion. In the isthmus there is a wide circular coat. The utero-tubal junction, included in the wall of the uterus, has no own muscular layer. The serosa is composed of a simple squamous epithelium overlying a thin loose connective tissue layer.

Concerning the presence and abundance of ciliated and secretory cells in the different segments of the oviduct, marked cyclic changes related with the period of the year were observed. In the fimbriae (Fig. 8) there are secretory cells and ciliated cells all over the year, nevertheless in ciliated cells cilia were never observed; secretory cells are the most abundant kind of cells and may have cytoplasmic protrusions, especially from the end of winter to the middle of spring. In the ampulla, ciliated cells, secretory cells and cells of the bottom of the folds compose the epithelium (Fig. 6). From the end of winter to the middle of spring, ciliated cells are more abundant, having numerous cilia, and secretory cells present cytoplasmic protrusions (Fig.7); during the rest of the year ciliated cells have no cilia and secretory cells predominate, having no protrusions (Fig. 6); the cells of the bottom of the folds have cilia from the end of winter to the end of spring. In the isthmus, the epithelium is taller than in the other portions of the oviduct and is made up of the same kinds of cells described for the ampulla; ciliated cells are more abundant than secretory cells during all the year and they present cilia only from the end of winter to the middle of spring (Fig. 9); secretory cells have no apical cytoplasmatic protrusions and cells of the bottom of the folds have cilia from the end of winter to the middle of autumn (Figs. 9, 10). In the utero-tubal junction secretory cells, without apical protrusions, predominate during all the year (Figs. 11, 12). Cells of the bottom of the folds have no cilia and ciliated cells have cilia only from the end of winter to the middle of spring (Fig. 12).

In brief, the ratio of ciliated cells to secretory cells varies both along the year and with the portion of the tube. The main variations occur in spring. The ciliated cells increase in number from the fimbriae, where they are nearly absent, to the distal portion of the oviduct, so been the isthmus practically covered by ciliated cells. The secretory cells are more abundant in the cranial portion of the ampulla and in the fimbriae, than in the isthmus. The number of cells of the bottom of the folds is similar in all portions.

Additionally to the characteristics here described for the oviduct in specimens collected from the end of winter to the middle of spring, bleeding in the vulva, mating behaviour, uterus ready for implantation and presence of a corpus luteum (data not shown), were observed. 
CODÓN, S. M. \& CASANAVE, E. B.Morphology and histological annual changes of the oviduct of Chaetophractus villosus (Mammalia, Xenarthra, Dasypodidae) Int. J. Morphol., 27(2):355-360, 2009

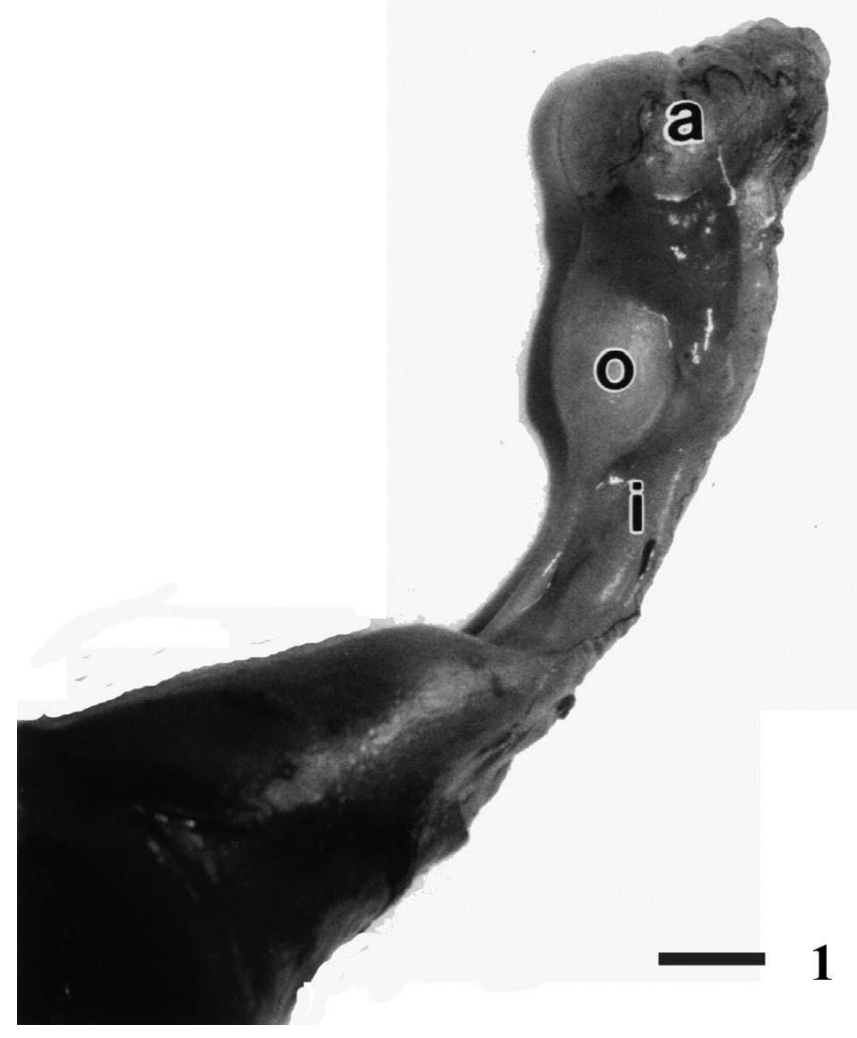

Fig. 1. Ventral view of the relations of the ovary with the oviduct in Chaetophractus villosus. a, ampulla; i, isthmus; o, ovary. Scale bar $=0.5 \mathrm{~cm}$.

Fig. 2. General view of the fimbriae. Masson. Scale bar $=50 \mu \mathrm{m}$.

Figs. 3, 4, 5. General view of a transversal section of:

3. Ampulla. Masson. Scale bar $=50 \mu \mathrm{m}$.

4. Isthmus. Masson. Scale bar $=50 \mu \mathrm{m}$.

5. Utero-tubal junction. PAS. Scale bar $=50 \mu \mathrm{m}$.
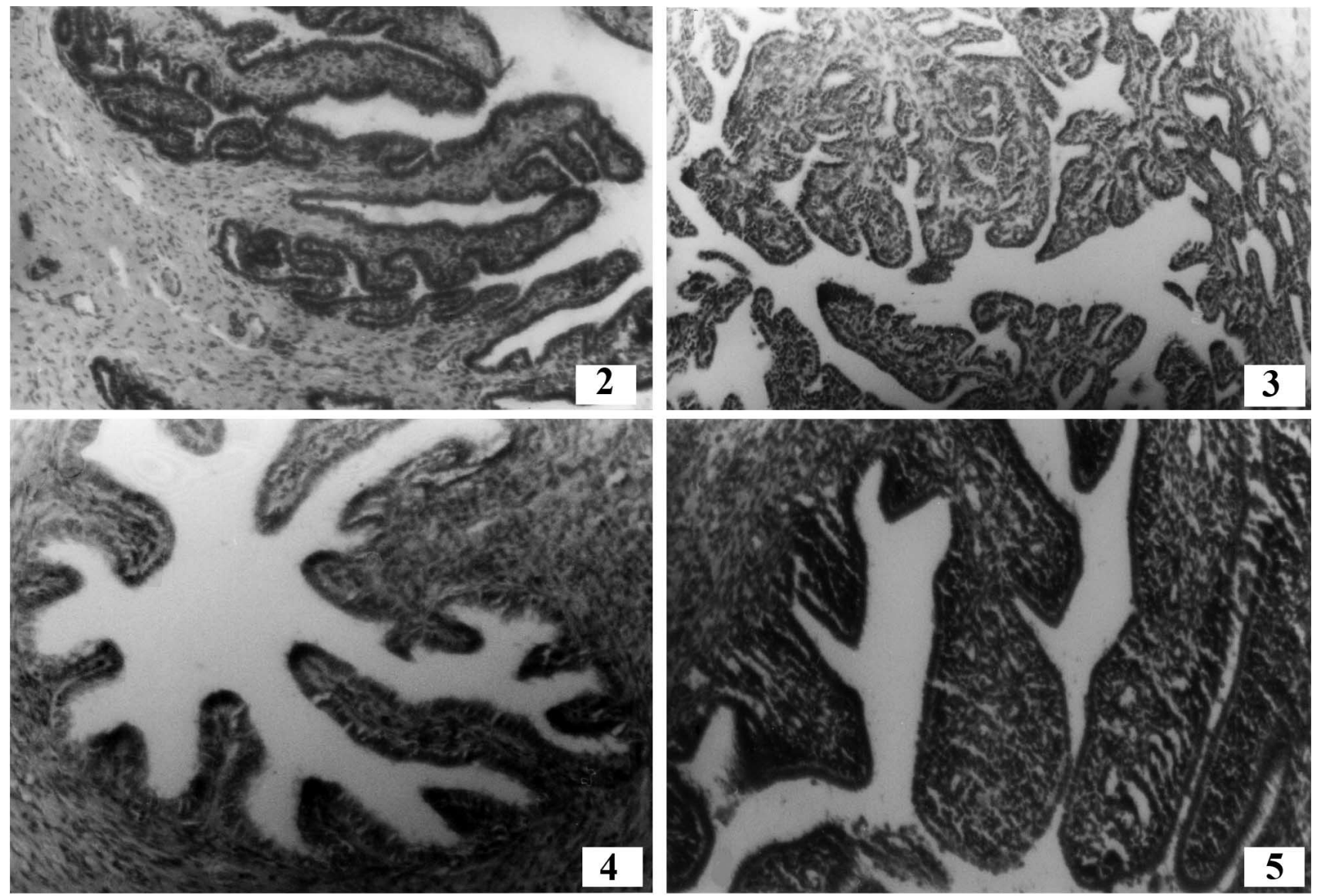

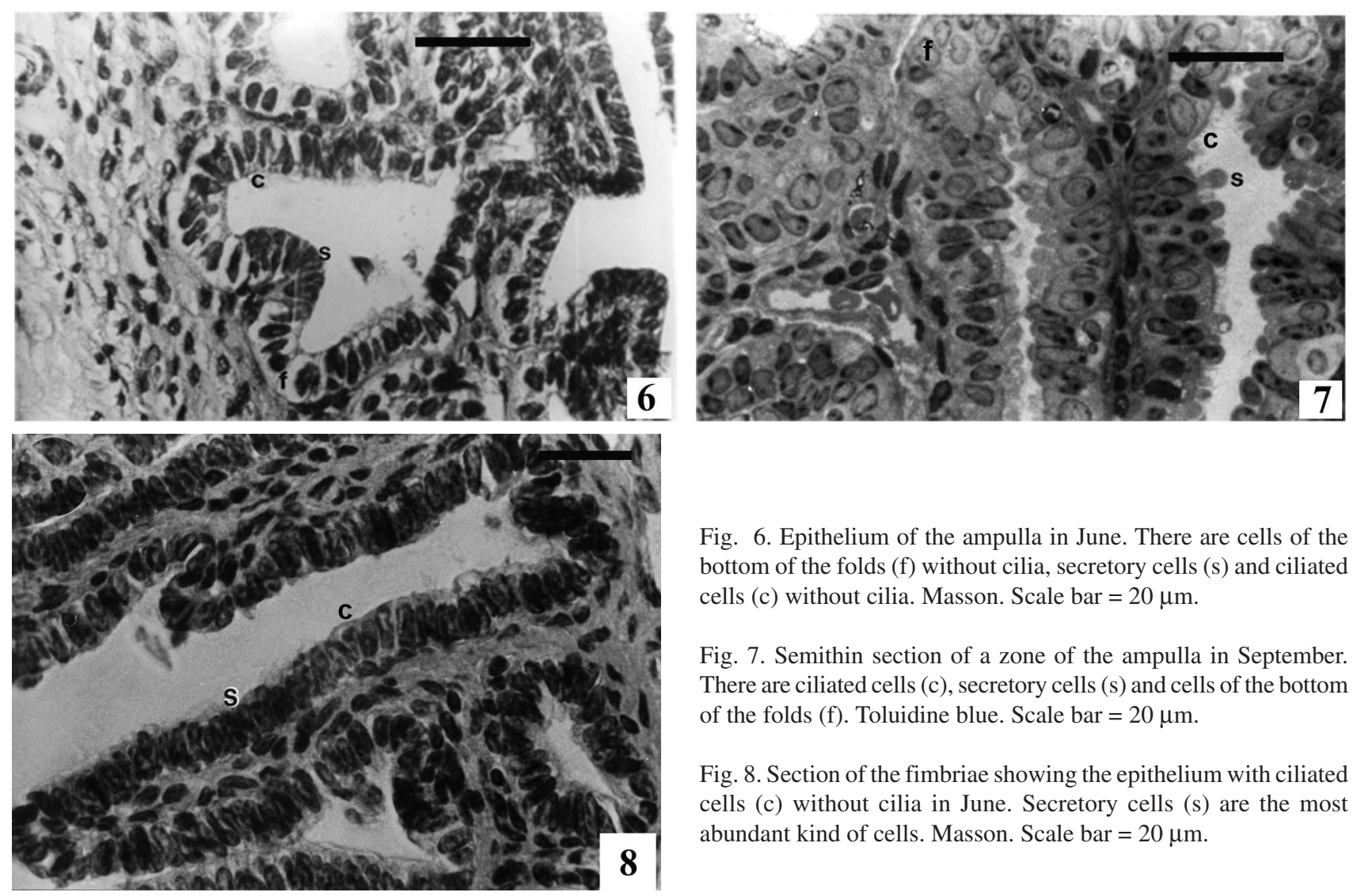

Fig. 6. Epithelium of the ampulla in June. There are cells of the bottom of the folds (f) without cilia, secretory cells (s) and ciliated cells (c) without cilia. Masson. Scale bar $=20 \mu \mathrm{m}$.

Fig. 7. Semithin section of a zone of the ampulla in September. There are ciliated cells (c), secretory cells (s) and cells of the bottom of the folds (f). Toluidine blue. Scale bar $=20 \mu \mathrm{m}$.

Fig. 8. Section of the fimbriae showing the epithelium with ciliated cells (c) without cilia in June. Secretory cells (s) are the most abundant kind of cells. Masson. Scale bar $=20 \mu \mathrm{m}$.
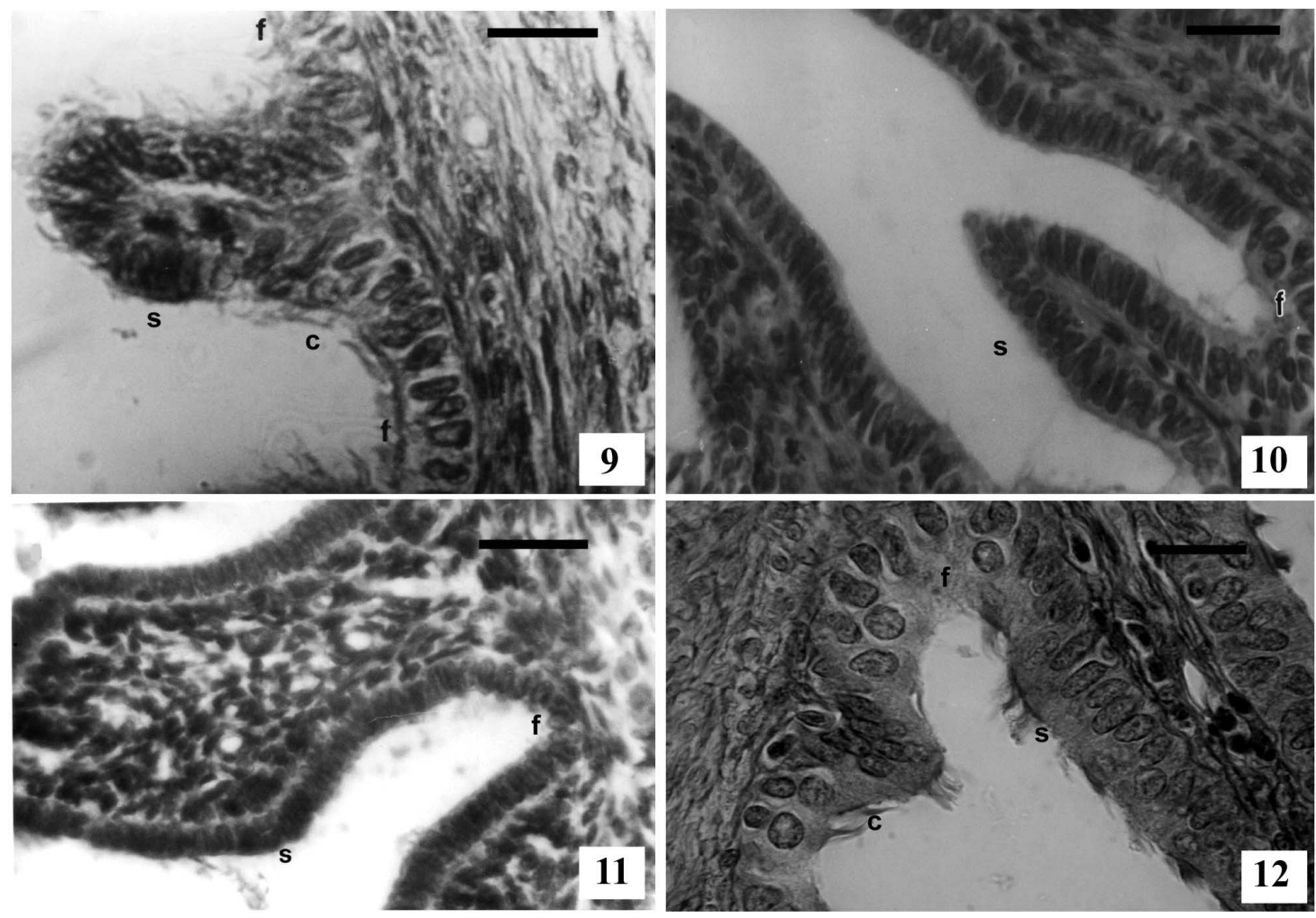

Figs. 9 - 12. 9. Isthmus in September. Ciliated cells (c) with cilia, secretory cells (s) and cells of the bottom of the folds (f) with cilia are observed. Masson. Scale bar $=20 \mu \mathrm{m}$. 10. Epithelium of the isthmus in May, cilia are not observed. Masson. Scale bar $=20 \mu \mathrm{m}$. 11. Folds of the utero-tubal junction in May with scarce ciliated cells. Secretory cells (s) and cells of the bottom of the folds (f) are observed. Masson. Scale bar $=20 \mu \mathrm{m}$. 12. Utero-tubal junction in September. Secretory cells (s), cells of the bottom of the folds (f) and ciliated cells with cilia are observed. Masson. Scale bar $=20 \mu \mathrm{m}$. 


\section{DISCUSSION}

The portions and macroscopic structure of the oviduct correspond basically with those described for other mammals (Kamaci et al.; Yániz et al., 2000, 2006). Although Cetica et al. said that the epithelium of the oviduct of C. villosus, and some other armadillos, is pseudostratified, in our animals it is simple ciliated columnar, as is described for other mammals (Eriksen et al., 1994; Kamaci et al.; Steffl et al.), including D. novemcinctus (Enders \& Buchanan) and D. hybridus (Cuba Caparo).

The ciliated cells and secretory cells are comparable with those described in other mammals (Abe \& Oikawa, 1991; Abe et al., 1999). Regarding the cells of the bottom of the folds, we think that they are cells in process of differentiation that could transform in secretory cells or ciliated cells.

The increasing wide of the muscular layer observed from the infundibulum towards the junction with the uterus, is according to the typical pattern of mammals (Eriksen $e t$ $a l$.). Even if the muscular coat arrangement in the isthmus is comparable, the one of the ampulla differ from $\mathrm{D}$. novemcinctus (Enders \& Buchanan), where scattered bundles of smooth muscle fibbers throughout their length were observed.

To the best of our knowledge, the cellular distribution observed in $C$. villosus is unusual in mammals, been typical the fimbriae ciliated and the isthmus though ciliated, mainly secretor (Abe et al., 1993; Crow et al., 1994; Kamaci et al.). Considering the function of the cilia in the isthmus, they would play a role in sperm reservoir and may contribute to regulate the progression of spermatozoa, as in other species (Hunter, 2005; Suarez \& Pacey, 2006; Pérez et al., 2006). The absence of cilia in the fimbriae of $C$. villosus remained to be explained.

The presence of cyclic changes of ciliation and the absence of changes in the characteristics of the secretory cells in the utero-tubal junction of $C$. villosus were also seen in bovine, species where there are ciliation around the period of oestrous (Wrobel et al., 1993), but not in goats, in which there are no changes of ciliation (Abe et al., 1993).

Finally, the end of the winter to the middle of spring, the period in which major histological changes were observed in the different portions of the oviduct of $C$. villosus, would correspond to the period of oestrous in our region.

CODÓN, M. S. \& CASANAVE, B. E. Morfología y cambios histológicos anuales del oviducto de Chaetophractus villosus (Mammalia, Xenarthra, Dasypodidae). Int. J. Morphol., 27(2):355-360, 2009.

RESUMEN: Se estudiaron las características morfológicas del oviducto del armadillo Chaetophractus villosus (Desmarest, 1804). En el epitelio, columnar simple, se describen células ciliadas, secretoras y células del fondo de los pliegues. Las células ciliadas, cuando están presentes, aumentan en número desde las fimbrias hacia el útero, estando el istmo prácticamente tapizado por células ciliadas, las células secretoras son más abundantes en la zona apical de la ampolla y en las fimbrias, que en el istmo. Se describen los cambios morfológicos en las diferentes porciones a lo largo del año.

PALABRAS CLAVE: Xenarthra; Armadillos; Chaetophractus villosus; Morfología; Oviducto.

\section{REFERENCES}

Abe, H. \& Oikawa, T. Regional differences in the ultrastructural features of secretory cells in the golden hamster (Mesocricetus auratus) oviductal epithelium. $J$. Anat., 175:147-58, 1991.

Abe, H.; Onodera, M. \& Sugawara, S. Scanning electron microscopy of goat oviductal epithelial cells at the follicular and luteal phases of the oestrus cycle. J. Anat., 183:415-21, 1993.

Abe, H.; Onodera, M.; Sugawara, S.; Satoh, T. \& Hoshi, H. Ultrastructural features of goat oviductal secretory cells at follicular and luteal phases of the oestrous cycle. $J$. Anat., 195:515-21, 1999.

Cetica, P. D.; Aldana Marcos, H. J. \& Merani, M. S. Morphology of female genital tracts in Dasypodidae (Xenarthra, Mammalia): a comparative survey. Zoomorph., 124(2):57-65, 2005.

Codón, S. M. \& Casanave, E. B. Histology of the ovary of the armadillo Chaetophractus villosus (Mammalia, Dasypodidae). Rev. Bras. Biol., 56(3):599-604, 1996. 
Codón, S. M. \& Casanave, E. B. Comparative morphology of the ovaries of three species of Daypodidae (Mammalia, Xenarthra). Rev. Chil. Anat., 18(2):251-7, 2000 .

Crow, J.; Amso, N. N.; Lewin, J. \& Shaw, R. W. Morphology and ultrastructure of fallopian tube epithelium at different stages of the menstrual cycle and menopause. Hum. Reprod., 9(12):2224-33, 1994.

Cuba Caparo, A. Atlas de histología del armadillo de 7 bandas (Dasypus hybridus). Buenos Aires, Centro Panamericano de Zoonosis, 1979. p.166.

Enders, A. C. \& Buchanan, G. D. The reproductive tract of the female nine - banded armadillo. Text. Rep. Biol. Med., 17(3):323-40, 1959.

Eriksen, T.; Terkelsen, O.; Grondahl, C. \& Brück, I. The equine oviduct. Histology and PDGF localization. Theriogenology, 41:191, 1994.

Hunter, R. H. F. The fallopian tubes in domestic mammals: how vital is their physiological activity?. Review. Reprod. Nutr. Dev., 45:281-90, 2005.

Kamaci, M.; Suludere, Z.; Irmak, K.; Can, C.\& Bayhan, H. Observation of isthmic epithelial cells from fallopian tubes at follicular phase by light and scanning electron microscope. Easterm J. of Medicine, 4(2):51-3, 1999.

Pérez, F. A.; Roma, S. M.; Cabada, M. O. \& Marini, P. E. Sperm binding glycoprotein is differentially present surrounding the lumen of isthmus and ampulla of the pig'soviduct. Anat. Embryol., 211(5):619-24, 2006.

Shirley, B. \& Reeder, R. L. Cyclic changes in the ampulla of the rat oviduct. J. Exp. Zool., 276(2):164-73, 1996.

Steffl, M.; Schwelger, M. \& Amselgruber, W. M. Immunophenotype of porcine oviduct epithelial cells during the oestrous cycle: a double-labelling immunohistochemical study. Histochem. Cell Biol., 121(3):239-44, 2004.

Suarez, S. S. \& Pacey, A. A. Sperm transport in the female reproductive tract. Hum. Reprod. Update, 12(1):23-37, 2006.

Wrobel, K. H.; Kujat, R. \& Fehle, G. The bovine tubouterine junction: general organization and surface morphology. Cell Tissue Res., 271:227-39, 1993.
Yániz, J. L.; López-Gatius, F. \& Hunter, R. H. F. Scanning electron microscopic study of the functional anatomy of the porcine oviductal mucosa. Anat. Histol. Embryol., 35:28-34, 2006.

Yániz, J. L.; López-Gatius, F.; Santolaria, P. \& June Mullins, K. Study of the functional anatomy of bovine oviductal mucosa. Anat. Rec., 260(3):268-78, 2000.

Correspondence to:

Stella Maris Codón

Laboratorio de Histología animal

Departamento de Biología, Bioquímica y Farmacia

Universidad Nacional del Sur (U.N.S.)

Bahía Blanca

ARGENTINA

Email: smcodon@criba.edu.ar

Received: 21-10-2008

Accepted: 03-03-2009 